\title{
REGISTRATIONS OF SEISMIC FOCI UNDER MINING COAL SEAM - THE EXPERIENCE OF POLISH MINES
}

\author{
Grzegorz MUTKE \\ Department of Geology and Geophysics, Central Mining Institute. 40-166 Katowice, Plac Gwarkow 1, Poland \\ Corresponding author's e-mail: gmutke@gig.eu
}

(Received July 2012, accepted November 2012)

\begin{abstract}
In the article the results of registering seismic events located under mining coal seam are presented. Such mining tremors have occurred in several Polish mines. The geological and mining conditions affecting the induction of that type of seismic events are shown. The mechanisms of deep seismic events (more than $1000 \mathrm{~m}$ ) triggered by mining are discussed in relation to regional geology.

The most deep mining seismic events in Upper Silesia were related to regional geological structures focusing stress (e.g. syncline) or tectonic structures (younger faults), where mining stresses were only additional factor to trigger strong regional seismic events. The tremors were characterized by a shear mechanism in the source (double-couple forces). Tremors located directly under the performed operation, usually characterized by an uniaxial tension mechanism, associated with the regional tension axis and the space created during the operation of the coal seam, causing pushing loaded rock-mass into new gobs. Proposed methods of seismic monitoring for case of seismic events location under mining coal seam are discussed.
\end{abstract}

KEYWORDS: depth of mining seismic events, location and mechanism of mining tremors

\section{INTRODUCTION}

Taken in the article subject is important in terms of understanding the mechanisms of mine tremors foci and in terms of the recognition of real impact of mining tremors on the underground excavations. Currently, it is fairly widely accepted that the operational mining tremors are associated with dynamic cracking of undermined rigid roof rock or an explosion of coal seam resulted from accumulation of elastic energy in the presence of stress concentration zones. Models of mining tremors, associated with cracking of strong, direct roof rocks, were intensive research in Polish coal mines in the last three decades (Bilinski, A., 1984; Drzewiecki, J., 1995, 2001; Marcak, 2011). Also in seam seismic events, associated with the local high static load of the coal seam or dynamic stress resulting from close mining tremors, was the subject of numerous studies (Drzewiecki, K., 1967; Szuścik and Zastawny, 1980; Ciałkowski and Mutke, 1994).

It is true that most mining tremors are the result of inelastic deformation of the direct strong roof layers. This point of view was confirmed by a lot of seismological observations in the mines. But now a number of seismic registrations are observed under extracted coal seam. In recent years, observations of deep tremors have been made possible by installing in a few mines the modern seismological network, allowing the reliable interpretation vertical position of the mining tremors foci (Fig. 2). For safety and economics of coal extraction the information on depth of mining tremors is very important. For example, sources of mining seismic events localized shallow under coal seam, require a different prevention than the mining tremors localized in direct rock roof. When the seismic events are located much deeper under mining coal seam and are far from excavations, the amplitude of ground motion are significantly damped and dynamic loads to mine workings are relatively low and don't cause danger to the stability of mine workings and miners (Dubiński and Mutke, 1996; Mutke, 2011; Dubiński and Mutke, 2012).The spatial location of seismic sources and analysis of their position in relation to mine workings is therefore essential for rockburst hazard assessment and thus for safety in operation. This is a very practical aspect of the study foci of deeper mining tremors. At present only occasionally we can meet research related to deep mining seismic sources and their mechanisms. Undoubtedly one of the reasons for this is in principle poor quality of seismic network in Polish mines in relation to small number of seismic stations and their spatial deploy. In general, there is so little opportunity to document the depth of recorded mining tremors. Analysis of mechanisms of mining tremors conducted in the Upper Silesia have shown, that shear mechanisms (dip-slip, strike-slip) are most popular for foci located in rock roof (Stec, 1992, 2007) and explosive mechanism for seismic sources located in coal seam. Also studied the mechanism of mining seismic events resulting from adding operating stress to existing residual tectonic stress were undertaken 


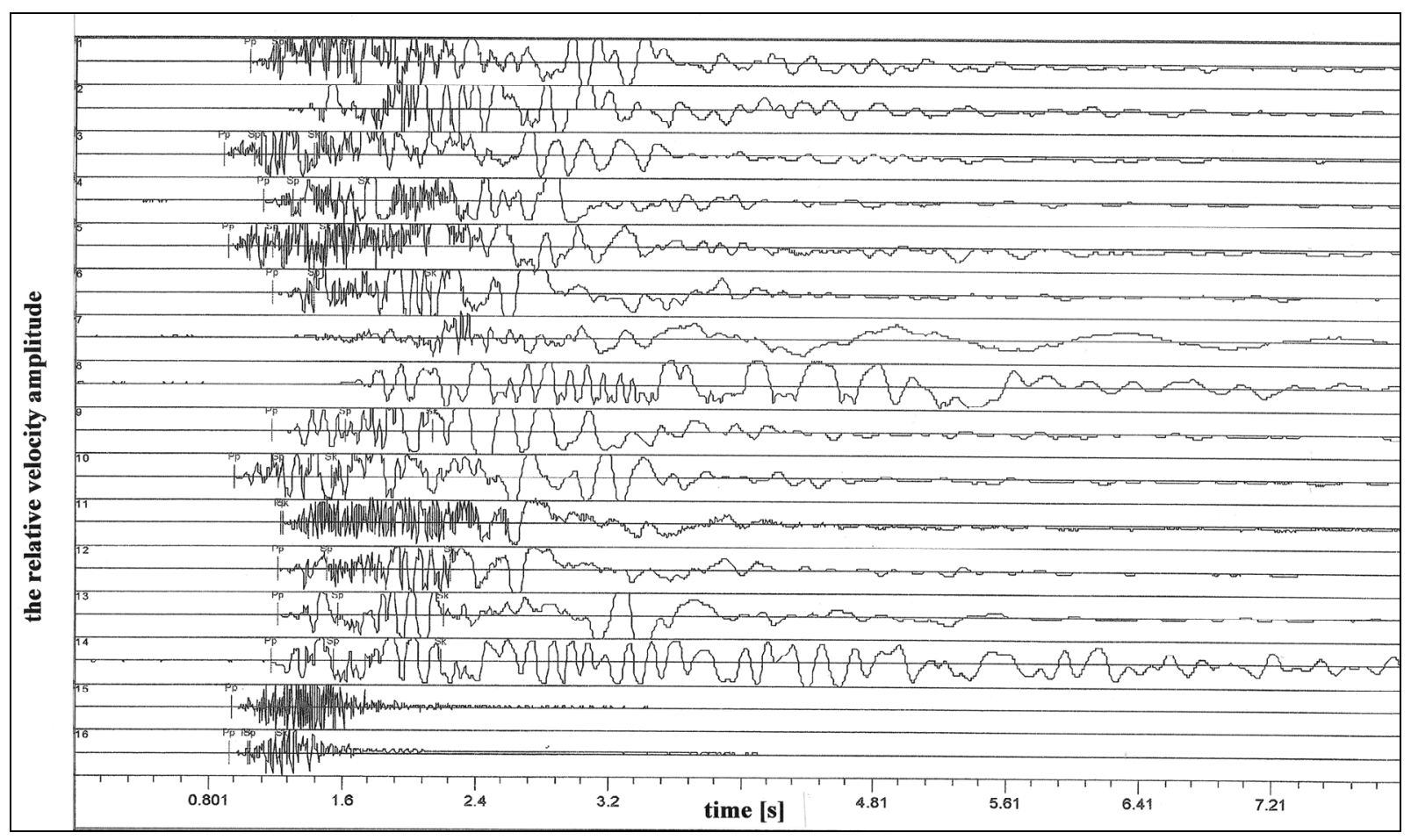

Fig. 1 Example of registering mining tremor on 1998.09.10, the seismic energy $\mathrm{E}=6 \cdot 106 \mathrm{~J}$ and the hypocenter located below the coal seam No 502 / K. The calculation made in the MULTILOK software in $3 \mathrm{D}$ version indicated the hypocenters deeper than $1000 \mathrm{~m}$.

(Mutke and Stec, 1997; Zuberek and Jochymczyk, 2010), but depth of mining seismic foci in such study only occasionally were calculated (Mutke and Stec, 2007).

\section{REVIEW OF PREVIOUS RESEARCH ON DEEP SEIMIC FOCI IN UPPER SILESIA - POLAND}

Review articles relating to the interpretation of the deep foci of mining shock, below the level of mining, should be start with the work of Professor Budryk and Janczewski. In 1955 was published in the Archives of Mining W. Budryk work under the title: The effects of earthquakes in the Upper Silesian coal mines (Budryk, 1955). Given the wealth of empirical evidence and the modest results of the seismic recording, Professor Budryk concludes that analyzed in the article, a very strong mining tremors from the area of Bytom city, had to occurred much deeper than level of extracted seams at that time. Damage to the few mines, could not have happened as a result of the relatively shallow roof rock seismic source.

At present, a lot of mining tremors are observed with hypocenters far from the active mined longwall face. For example, the GIG's Upper Silesian Regional Seismic Network records the strong mining seismic events in various parts of a large Klodnicki fault. The article (Mutke et al., 1999), presents the results of the depth study of foci of severe strong mining tremors occurring during the operation of the longwall panels 1 and 2 in seam $502 / \mathrm{K}$, while departing from the plane of large and renewed in Quaternary Klodnicki fault in the NNE direction. Mine seismic network (14 stations at panel K), were additionally extended by two geophones placed in the borehole $100 \mathrm{~m}$ above the seam $\mathrm{N}^{\circ} 502$ and $100 \mathrm{~m}$ below the seam $\mathrm{N}^{\mathrm{o}} 502$. Within four months 10 mining tremors with seismic energy from $4 \cdot 10^{5} \mathrm{~J}\left(\mathrm{M}_{\mathrm{L}}=2.06\right)$ to $6 \cdot 10^{6} \mathrm{~J}\left(\mathrm{M}_{\mathrm{L}}=2.71\right)$, were recorded with sources at a depth of over $1000 \mathrm{~m}$ to $1200 \mathrm{~m}$ (depth of the coal seam $\mathrm{N}^{\circ} 502 / \mathrm{K}$ is approximately $900 \mathrm{~m}$ ). Location was based on recorded seismograms by SOS seismic network and using MULTILOK software allowing calculating foci in $3 \mathrm{D}$ version. Seismometers were deployed vertically from the surface to a depth of $950 \mathrm{~m}$ and ensure high reliability of determining the vertical component of the foci, with an error less than $50 \mathrm{~m}$. Additionally, these 10 recorded seismograms were characterized by the direction of the first swing to the top in all channels, which meant that the seismic waves were likely to come from the bottom in relation to seismometers (Fig. 1). Deep location of mining tremors were confirmed by indication of geophones placed in boreholes $100 \mathrm{~m}$ above coal seam $\mathrm{N}^{\mathrm{o}} 502$ and $100 \mathrm{~m}$ under the coal seam $\mathrm{N}^{\circ} 502$.

Further analysis of the mechanisms of these mining seismic events showed that the operation changed the unstable state of young tectonic at Klodnicki fault, about $150 \mathrm{~m}$ below the level of mining. All tested shocks were characterized by the action of shear forces in the sources (ND dip-slip 
normal fault). The nodal planes trend and plunge were oriented similarly to the strike direction and dip of the Klodnicki fault (strike: $\Phi \mathrm{A}=200^{\circ}-280^{\circ}$ and dip: $\left.\delta \mathrm{A}=50^{\circ}-80^{\circ} \mathrm{S}\right)$. The mechanism of full tensor solution analyzed mining tremors contained about $10 \%$ of the isotropic, about $10 \%$ of the component uniaxial compression and about $80 \%$ of the best fitting double-couple forces (shear component). Pressure axis $\mathrm{P}$ was directed at an angle close to the dip angle of Klodnicki fault and tension axis $\mathrm{T}$ was directed toward the north and under low angle of about $20 \%$, similar to the direction of inclination of the coal seam $\mathrm{N}^{\mathrm{o}} 502$ and the adjacent layers. The mining caused a change in the balance of principal stresses and increasing horizontal stress, increased shear stress and initiated the process of cracking the rock. It is worth noting that the weak feeling in the workings so strong mining tremors could result from the fact that the stress wave pulse in the near field is strongly oriented and its greatest value is directed perpendicular to the plane of slip. In our case, the maximum stress pulses can propagate almost horizontally, according to the inclination of coal seam $\mathrm{N}^{\mathrm{o}} 502$. With deep foci of mining tremors, these wave stress impulses came under the excavations of the coal seam $\mathrm{N}^{\mathrm{O}} 502$ and didn't cause damage to the mine workings.

In the next article (Mutke and Stec, 2007) the mining tremor of 2007.09.02 and the seismic energy $1 \cdot 10^{9} \mathrm{~J}$ was analyzed, during mining longwall face $\mathrm{N}^{0} 1$ in coal seam $\mathrm{N}^{\circ} 503$ at a depth of $750 \mathrm{~m}$ and in the $\mathrm{S}$ direction in coal mine Bobrek. Location of this seismic event was done spatial (3D) using MULTILOK software and based on the time of first wave arrival. Depth of seismic stations was varied from $-338 \mathrm{~m}$ to $-894 \mathrm{~m}$ below surface, allowing performing a reliable calculation of the vertical component of seismic source. The result indicated that the depth of focus was around $1250 \mathrm{~m}$ (below surface), i.e. the $500 \mathrm{~m}$ deeper than coal seam $\mathrm{N}^{0} 503$. Seismic source located $500 \mathrm{~m}$ below seam 503 points to its genesis related to the geology of Bytom syncline along their bottom axis. The depth location of seismic source was confirmed by the best-fit solution of the seismic moment tensor, defined on the basis of quality factor Q solution (Quality Index). The slightest adjustment error ERR was obtained for a depth of $1280 \mathrm{~m}$ from the surface, similar to location result using Powel algorithm. It was also considered other indirect evidence of deep foci location of the analyzed this strong mining seismic event. The macroseismic observation shows that the maximum intensity of the vibration according to MSK scale, reached at the epicenter degree of $\mathrm{I}_{0}=6$, and 2.5 kilometers from the epicenter, the intensity resulted the degree of $\mathrm{I}=4$. Using the formula for the intensity of vibrations with distance and depth (Bath, 1973):

$$
\mathbf{I}_{0}-\mathbf{I}=3 \log \left[\left(r^{2}+h^{2}\right) / h^{2}\right]
$$

Where $h$ is the foci depth [km] and $r$ is the epicentral distance $[\mathrm{km}]$.

After analyzing the macroseismic effects of 2007.02.09 mining tremor using equation 1, for the foci depth of $1.25 \mathrm{~km}$ we get at epicentral distance equal of $2.5 \mathrm{~km}$, intensity degree of $\mathrm{I}=4$. This result agrees with macroseismic observation. The mechanism of full tensor solution analyzed mining tremor indicates the double-couple mechanism with shear forces. The nodal planes trend were oriented similarly to the strike direction of the bottom axis of Bytom Basin (strike NW-SE: $\Phi \mathrm{A}=165^{\circ}$ ). The mechanism of full tensor solution analyzed strong mining tremor indicated dominant shear of the double-couple solution $(91.2 \%)$. The mechanism of 2007.02.09 mining tremor with seismic energy $1 \cdot 10^{9} \mathrm{~J}$ was determined as the type of "reverse" with pressure axis in horizontal direction and tension axis in vertical direction. Reverse mechanism can cause squeezing rocks in the direction opposite to the force of gravity. Heterogeneity in the process of deformation of rocks to the top is what causes strong mining tremors in analyzed case study.

In the article of Professor Drzewiecki (Drzewiecki, 2009) the seismicity related to mining of five longwall faces in coal seam $\mathrm{N}^{\mathrm{0}} 409$ at a depth of $990 \mathrm{~m}-1090 \mathrm{~m}$ in the Silesia coal mine are described. First coal mining in this area was accompanied by high seismic activity and the occurrence of some very strong regional shocks, with a maximum of seismic energy $8 \cdot 10^{8} \mathrm{~J}$. Strong mining seismic events were located at great depth, from $1200 \mathrm{~m}$ to $1500 \mathrm{~m}$. The operation took place between crossed two major faults. Fault Kłodnicki (strike in WS direction and magnitude of the slip $150 \mathrm{~m}-360 \mathrm{~m}$ in S direction), and fault VIa (strike in NNE-SSW direction and magnitude of the slip $50 \mathrm{~m}$ in SE direction). In this case, an increase in the degree of freedom of solid rock in a one of fault VIa wing took place. Tectonic stress has given the opportunity to release energy in the form of strong seismic events. Such a geomechanical mechanism hypothesis confirms the seismic moment tensor study of the strongest shocks. They were characterized by a shear mechanism and the nodal plane trend was in NE-SW direction (such as the fault VIa).

The next article (Stec, 2011) presents the results of investigations of seismic source mechanism during operation of longwall panels 1,2 and 3 in coal seam $\mathrm{N}^{0}$ 503. The longwalls 1,2 and 3 in the final phase came to a bottom line of Bytom Basin and caused the occurrence of very strong seismic events. Depth of seismic sources was evaluated on the basis of solution quality factor Q (Quality Index). In the first phase of the operation the roof tremors occurred most often. The second group was characterized by foci of shocks located $20 \mathrm{~m}$ under floor. The third group were related with strong seismic tremors at the great depth, about $500 \mathrm{~m}$ below mined coal seam $\mathrm{N}^{\mathrm{O}} 502$. The second and third group of seismic events under the level of 
mining was characterized by a reverse mechanism. Under Bytom syncline axis there is a discontinuity in the crystalline rocks, running in W-E direction. The analysis of seismic mechanism revealed, that even the small change in compression and tension stresses can activated the local tectonics and triggered strong seismic events.

\section{THE RESULTS OF EXPERIMENTAL MONITORING OF DEEP MINING SEISMICITY - CASE STUDY IN WUJEK-SLASK MINE, LONGWALL PANEL 2JD}

To test the thesis of the location of part of the mining tremors foci below the level of extracting coal seam, Central Mining Institute installed modern underground seismic network at field site around longwall face 2JD in coal seam $\mathrm{N}^{\mathrm{O}} 502$ in mine Wujek-Slask. This monitoring was done under ADEMA RFCS project. To ensure reliable spatial location of mining tremors around longwall face 32channel Seismic Observation System SOS was installed and appropriate software for the 3D location was used to analyze recorded mining tremors. The difference of first arrival time of seismic wave for individual seismic stations methods was used to location of recorded mining tremors. Seismic stations were well deployed at vertical direction, giving possibility of depth location accuracy of less than $100 \mathrm{~m}$. A few geophone stations were three components. These stations allowed for verification of the depth of mining tremors foci, using S-P location method. With the assumption no error of wave propagation velocity adopted for $\mathrm{Vp}=3800 \mathrm{~m} / \mathrm{s}$ and acceptance of the accuracy of time difference on seismic station of $\mathrm{tp}-\mathrm{ts}=0.015 \mathrm{~s}$, the error location could be up to $57 \mathrm{~m}$. Effect of inaccurate assumption $\mathrm{Vp}$ velocity of $200 \mathrm{~m} / \mathrm{s}$ deviation of average value $\mathrm{Vp}=3800 \mathrm{~m} / \mathrm{s}$, could cause at hypocentral distance of $1000 \mathrm{~m}$ the error of $53 \mathrm{~m}$. Distribution of the seismic stations in vicinity of longwall panel 2JD is shown in Figure 2.

During almost two years of continuously measurements, from July $1^{\text {st }} 2007$ to April $30^{\text {th }} 2008$, more than 700 seismic events from the area of longwall 2JD seam 502 were recorded. The location of tremor foci were based on methods relating to the first arrivals of longitudinal P-waves and first arrivals of shear S-waves (Fig. 3). To calculate seismic events location errors in the area of face $\mathrm{N}^{\mathrm{O}} 2 \mathrm{JD}$ in WujekSlask mine, the novel approach was introduced based on implicit function theory and on statistical theory (Lurka, 2000). The location error near-by face $\mathrm{N}^{\circ}$ 2JD was from $30 \mathrm{~m}$ to $50 \mathrm{~m}$. In addition, velocity for every seismic station was calculated. It allows improving accuracy of location of seismic events. 3D locations of strongest seismic events have shown that approximately $70 \%$ of the source locations had been identified to lie beneath the coal seam, whilst $20 \%$ lay above the seam at this case study (Fig. 4). These seismic events occurred far from workings and face line of longwall 2JD. Only a few strong seismic events were located in seam 502, close to face of longwall 2JD. The reason of deep location of seismic sources at field site results from the local tectonic. Below coal seam $\mathrm{N}^{\circ} 502$ extends the large faults west from longwall 2JD fault V (strike direction SW$\mathrm{NE}$, slip 65m) and south from longwall 2JD fault Klodnicki (strike direction E-W, slip 365m).

\section{CONCLUSION}

Most mining tremors recorded by mining seismic network in Polish coal mines has its place in the roof rock or in coal seam.

In the last few years we have recorded more and more mining tremors localized deeper than level of mined coal seam. The reason for this change was to install in a few Polish mines the modern seismological network consisting of 32 or 64 channels and welldistributed spatially seismic stations, particularly in vertical direction.

The most deep mining seismic events in Upper Silesia were related to regional geological structures focusing stress (e.g. syncline) or tectonic structures (younger faults), where mining stresses were only factor triggering tectonic seismic events. The deep tremors were characterized by a shear mechanism in the source (double-couple force solution. Tremors located directly under the coal seam floor very often were characterized by essential contribution of compensated linear vector dipol mechanism CLVD (uniaxial force solution). It could be means that we have relatively large horizontal uniaxial compression comparing to vertical one, $\sigma_{3}$. During mining are created new gobs. In such case the rock slabs are pushed up to empty space in the new gobs (vertical extension).

The spatial location of seismic sources and analysis of their position in relation to mine workings is essential for rockburst hazard assessment for choice of prevention methods and thus for safety in operation. This is a very practical aspect of the study foci of deeper mining tremors.

\section{ACKNOWLEDGEMENT}

Partly this article is the result of the research study in ADEMA project Advances in Exploration Methods and Applications RFCR-CT-2005-00001, supported by the Research Fund for Coal and Steel.

\section{REFERENCES}

Final Report of the ADEMA Project: 2008, Advances in Exploration Methods and Applications. RFCR-CT2005-00001 (WP3).

Bath, M.: 1973, Introduction to seismology. Birkhauser Verlag Basel. 395 pp.

Biliński, A.: 1984, Bumps in the light of relaxed rock mass. Komunikat GIG. Katowice, (in Polish).

Budryk, W.: 1955, The effects of earthquakes in the Upper Silesian mines. Archives of Mining and Metallurgy. T. III, Z. 2, 227-240, (in Polish).

Cialkowski, B. and Mutke, G.: 1994, Influence of support load-bearing capacity on the range and effects of 

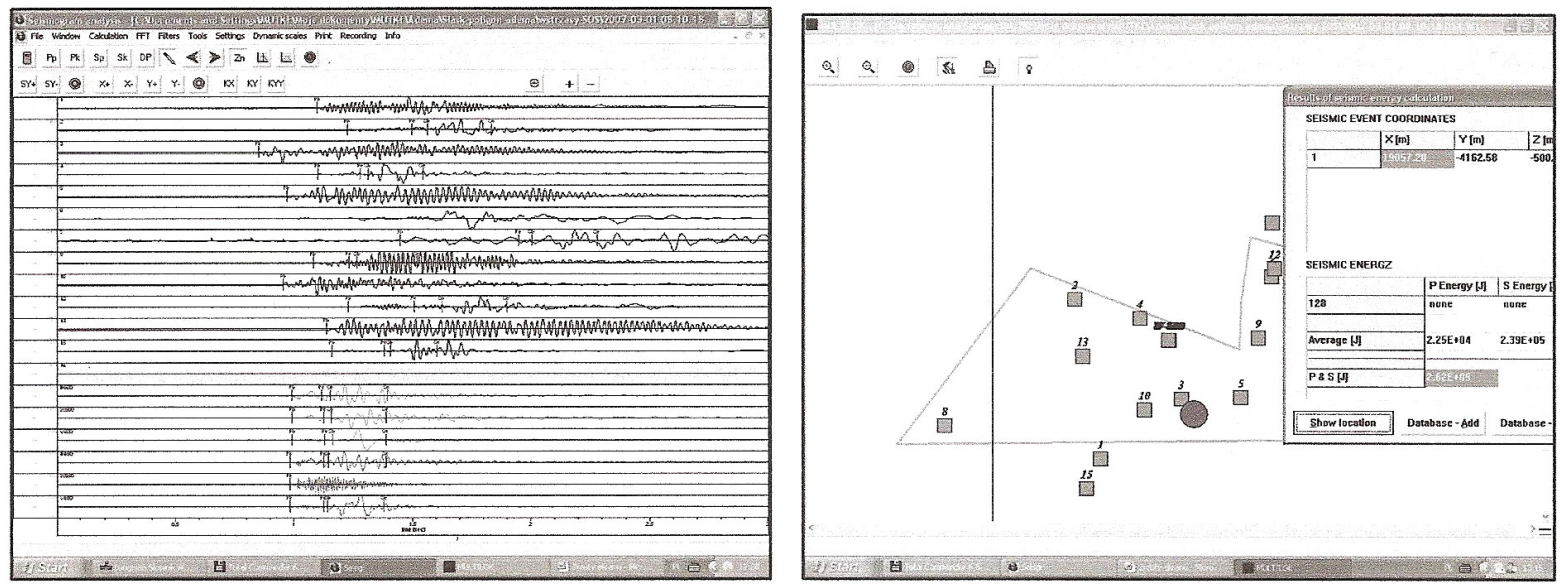

Fig. 3 Recorded file and picked sign of seismic wave using SEJSGRAM software (left site of Figure 3) and location of seismic event using MULTILOK software (right site of Figure 3).

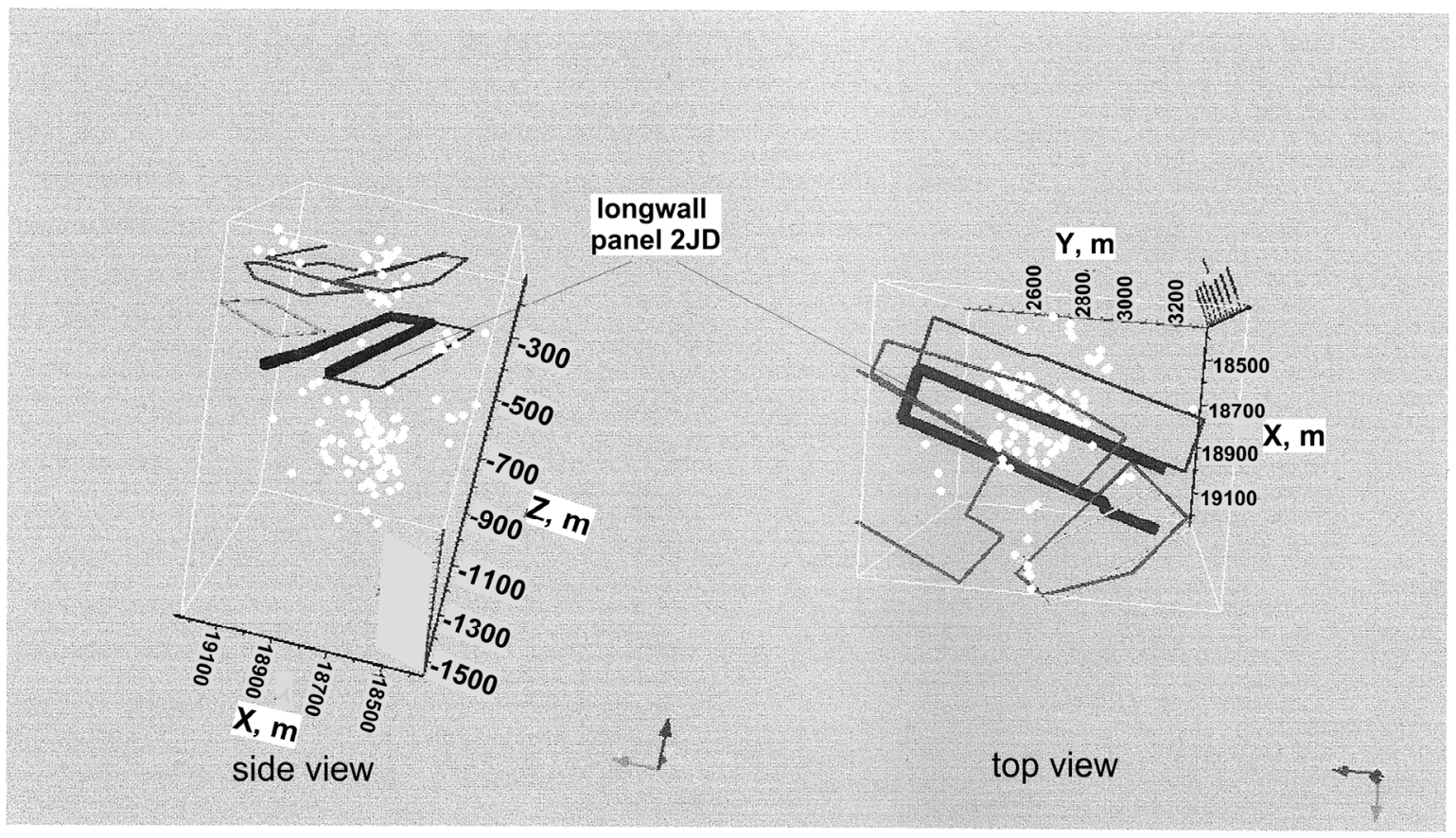

Fig. 4 Example of 3D location of seismic events in "Wujek-Slask" mine recorded by Seismic Observation System SOS. On the left picture - side view and on the right picture - top view (gray dots - hypocenter of seismic events, thick line - contour of longwall 2JD, thin lines - edges).

rockburst in dog heading. Prace Naukowe Instytutu Geotechniki i Hydrotechniki Politechniki Wrocławskiej - No. 65, Conference no. 33. (Scientific work of Wroclaw University), 23-32, (in Polish).

Drzewiecki, K.: 1967, Discharge of elastic energy in the collapse of a fragile material. Selected problems of rock mechanics. Prace Komisji Nauk Technicznych PAN. Górnictwo, z. 4, (in Polish).

Drzewiecki, J.: 1995, The mechanism of the splitting of the strengths of roof rocks in the light of in-situ measurements. Prace Naukowe GIG (Scientific works of GIG Katowice) No. 804, (in Polish).
Drzewiecki, J.: 2001, Dependence of active volume of rock mass on the longwall coalface advance rate. Archives of Mining, 3-18.

Drzewiecki, J.: 2009, High energy seismic phenomena with foci located at great depth under the extracted seam. Prace Naukowe GIG (Scientific work of GIG), No. 4/1, 89-98, (in Polish).

Dubiński, J. and Mutke, G.: 1996, Characteristics of mining tremors within the near-wave field zone. PAGEOPH, 147, No. 2, 249-261.

Dubiński, J. and Mutke, G.: 2012, Application of PPV metod for the assessment of stability hazard of 
underground excavations subjected to rock mass tremors. AGH Journal of Mining and Geoengineering. Quarterly of AGH University of Science and Technology, 36, No. 1, 125-132.

Lurka: 2000, Error analysis of mining tremors foci location using the implicit function. $\mathrm{PhD}$ thesis, GIG, Katowice, (in Polish).

Marcak, H.: 2011, The seismic activity due to the banding of exploited seam roof. Proceeding of 11 World Mining Congres, Istanbul 2011.

Mutke, G. and Stec, K.: 1997, Seismicity in the Upper Silesian Coal Basin, Poland: Strong regional seismic events. Proc. 4th Int. Symp. :Rockbursts and Seismicity in Mines, ed. S.J. Gibowicz. Rotterdam, A.A. Balkema, 213-217.

Mutke, G., Stacha, G. and Bubała, C.: 1999, On the depth of mining tremors foci occurred during the operation the walls 1 and 2 on-board $502 / \mathrm{K}$ in the Silesia coal Mine. Prace Naukowe GIG (Scientific works of GIG Katowice), 113-122, (in Polish).

Mutke, G. and Stec, K.: 2007, Analysis of the mechanism and source parameters of the shock on 2007.09.02 on seismic energy $\mathrm{E}=1 * 10^{9} \mathrm{~J}-$ regional nature, No. 3, 337-346, (in Polish).

Mutke, G.: 2011, The evaluation of the potential hazard of workings stability longwall excavation under seismic load. Prace Naukowe GIG (Scientific works of GIG Katowice), No. 4/2, 327-335, (in Polish).
Stec, K.: 1992, Results of the study of mechanism of tremors in the Szombierki coal mine. Acta Montana, $84,43-50$

Stec, K.: 2007, Characteristic of seismic activity of the Upper Silesian Coal Basin in Poland. Geophysical Journal International. Blackwell Publishing Ltd., 168, 757-768. DOI: 10.1111/j.1365-246X.2006.03227.x

Stec, K.: 2011, Informativity of the method of tremor foci mechanism determination in the approximation of rock mass destruction processes. Prace Naukowe GIG (Scientific works of GIG Katowice), No 4/2, 439-450, (in Polish).

Szuścik, W. and Zastawny, E.: 1980, The phenomenon of the coal material bursting. Przeglad Górniczy, No. 11, (in Polish).

Zuberek, W.M. and Jochymczyk, K. (eds.): 2000, The origins and characteristics of seismic hazard in USBC. Prace Naukowe Uniwersytetu Śląskiego w Katowicach (Scientific Work of Silesian University), No 2764, (in Polish). 


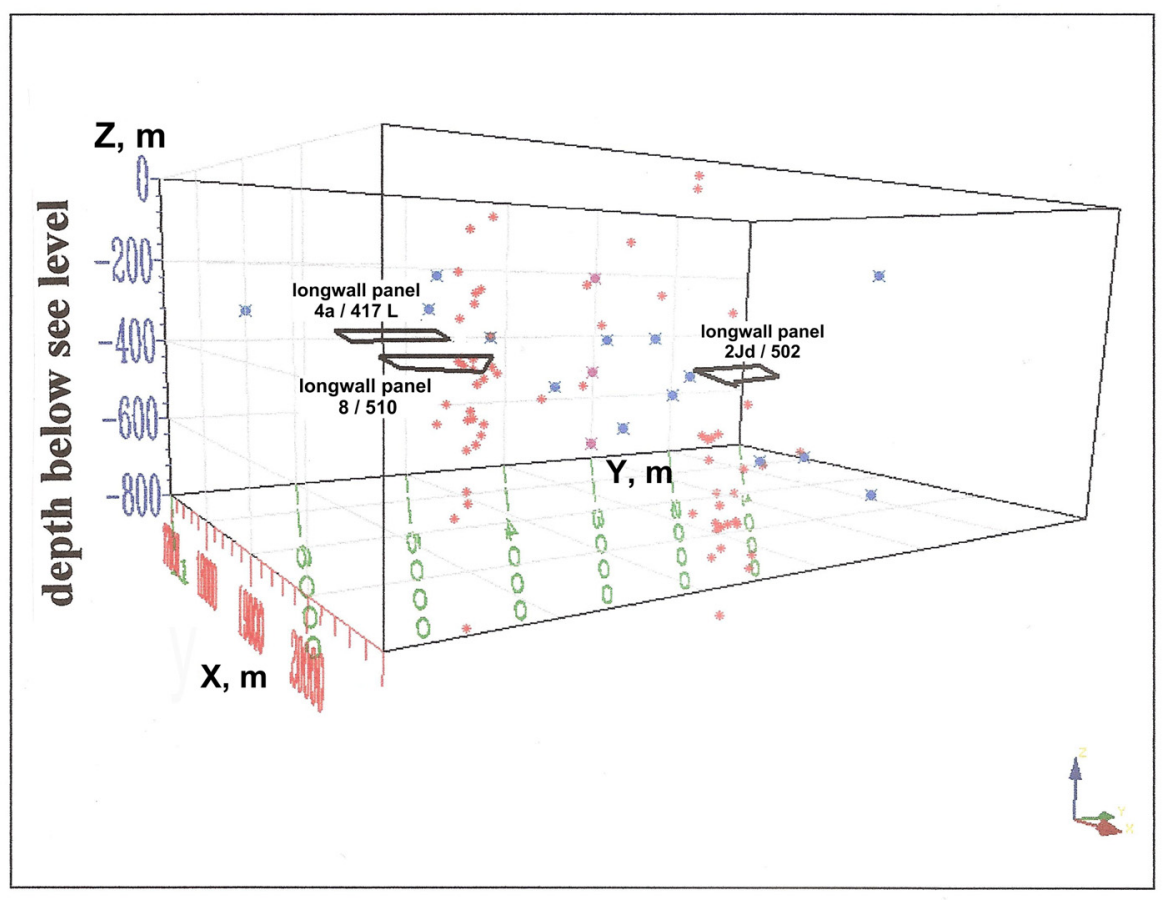

Fig. 2 Deploy of the seismic stations around the longwall panel 2JD at WujekSilesia coal mine (blue circles) and some registered strong mining seismic events (red dots). 